\title{
Effect of all-trans retinoic acid (ATRA) against expression of matrix metalloproteinase-2 (MMP-2) in model mice (Rattus norvegicus) periodontitis
}

\author{
Ilma Soraya*, Nadya Octoraputri Herdiana*, Rifan Hanggoro*, Haris Budi Widodo** \\ *Department of Dental Medicine of Universitas Jenderal Soedirman Purwokerto, Indonesia \\ **Department of Periodontic, Faculty of Dentistry, Universitas Jenderal Soedirman Purwokerto, \\ Indonesia
}

\begin{abstract}
Introduction: Periodontitis is a common chronic inflammatory disease characterised by destruction of the supporting structures of the teeth, generally caused by bacteria Phorphyromonas gingivalis (P.g). Matrix metalloproteinase-2 (MMP-2) is an enzyme that plays an important role in inflammatory conditions. All-trans retinoic acid is a metabolite of vitamin A which plays a role in healing the inflamed tissue and maintain the immune system. The purpose of this study was to determine the effect of ATRA on the expression of MMP-2 in periodontitis models of mouse Rattus norvegicus. Methods: this was a laboratory experimental study using post-test only with control group design. This study used 25 male Wistar mice that was divided into 5 groups. Group 1 is a group of healthy mice, Group 2 is a group of periodontitis induced mice without treatment, Group 3 is a group of periodontitis mice treated with $5 \mathrm{mg} / \mathrm{kgBW}$ doses of ATRA, Group 4 is a group of periodontitis mice treated with $10 \mathrm{mg} / \mathrm{kgBW}$ doses of ATRA, and Group 5 is a group of periodontitis mice treated with $20 \mathrm{mg} / \mathrm{kgBW}$ doses of ATRA. The periodontitis was induced using Phorphyromonas gingivalis bacteria every 3 days for 28 days and followed by administration of ATRA for 7 days. Expression of MMP-2 from gingival tissues and periodontal ligament was obtained by immunohistochemical methods. The results were analyzed using the Shapiro-Wilk Test and Mann-Whitney Test. Results: The results showed there were significant differences in the positive area of MMP-2 and MMP-2 color intensity $(p<0.05)$ between Groups. Conclusion: ATRA dose of $20 \mathrm{mg} / \mathrm{kgBW}$ is the most effective dose in inhibiting the expression of MMP-2 in mice models of periodontitis when compared with other doses.
\end{abstract}

Keywords: Periodontitis, all-trans retinoic acid (ATRA), MMP-2 expression

P-ISSN 1979-0201, e-ISSN 2549-6212 Available from:http://jurnal.unpad.ac.id/pjd/index

DOI:http://dx.doi.org/10.24198/pjd.vol29no2.13612

Submission: May 2017 Publishing: July 2017

Corresponding author: Ilma Soraya, Department of Dental Medicine of Universitas Jenderal Soedirman, Purwokerto Indonesia, 53122. Email: soraya.ilma@yahoo.com 


\section{INTRODUCTION}

Periodontal disease is an oral cavity illness that is most suffered to human being until nowadays. The survey result of Household Health Survey (SKRT) in 2004 told that the prevalence of periodontal disease in Indonesia has reached $96.85 \%$. A type of periodontal disease which is often suffered in many cases is periodontitis. Periodontitis is an inflammation of the periodontal tissues or teeth supporting tissues. ${ }^{1}$ Periodontitis is usually caused by Porphyromonas gingivalis bacteria which is known as the most aggresive bacteria that can induce the condition. That bacteria produces toxin which can hamper fagositosis, degrades imunoglobulin, and triggers pro-inflammatory cytokines. $^{2}$

In periodontitis, there are enhancements of macrophage and osteoclast cell numbers. Macrophage and osteoclast are the cells producing proteolytic enzymes, the matrix metalloproteinase enzymes. Thus, in periodontitis, the production of this enzyme is increasing. The matrix metalloproteinase enzyme (MMP) will damage the collagen that dominates the periodontal ligament. So, in a periodontitis case, enhancement of collagen degradation condition will be found. ${ }^{3}$ From various MMP types, MMP-2 is known as an agent that signals collagen degradation of the periodontal tissues, where this condition is very specific. The expression and the activity of this enzyme are predictive indicators for periodontitis condition. ${ }^{4}$

Today many kind of efforts have been developed to act against that MMP enzyme activity. One that is alleged to inhibit MMP activities is vitamin A metabolite. The consumption of high quality vitamin $A$ is very low in Indonesian citizen. ${ }^{5}$ Vitamin A metabolite which is known as all-trans retinoic acid (ATRA) is considered to function in all condition. Vitamin A metabolite is judged to be able to potentially press damages of inflammatory conditions. ${ }^{6}$ In this case, ATRA works by pressing inflammatory cell infiltration with cytokines anti inflammatory enhancement (IL-10, TGF-beta) and by reducing the production of cytokines pro inflammatory such as IL-1 and TNF-alfa. The other way of how ATRA works is by modulating Th-17 cell and keeping the sync T-regulator cell. It has the role as body protector towards infection. ${ }^{7}$
The ATRA dosage exertion per day which is safe for the mouse is $20 \mathrm{mg} / \mathrm{kgBW}$. Other ATRA dosages of $5 \mathrm{mg} / \mathrm{kgBW}, 10 \mathrm{mg} / \mathrm{kgBW}$, and $15 \mathrm{mg} /$ $\mathrm{kgBW}$ are known to be able to help the healing process of soft tissue inflammation. ${ }^{8} \mathrm{~A}$ healing method for periodontitis with ATRA measured through MMP-2 activity has not been found, so this research needs to be done in order to understand the effect of ATRA dosage variation towards mouse model MMP-2 expression which is induced by periodontitis.

\section{METHODS}

The research methods were laboratory experimental and post-test only control Group design which contained 5 groups. Group 1 was a mice group which was not induced by periodontitis and was not given ATRA, Group 2 periodontitis mice Group which was not given ATRA, Group 3 was periodontitis mice group which was given the ATRA of $5 \mathrm{mg} / \mathrm{kgBW}$ dosage, Group 4 was periodontitis mice group which was given ATRA of $10 \mathrm{mg} / \mathrm{kgBW}$ dosage, and Group 5 was periodontitis mice group which was given ATRA of $20 \mathrm{mg} / \mathrm{kgBW}$.

In this research, used healthy white mice (Rattus norvegicus) of Sprague dawley, 3-4 months old, weight of 200-300 grams, male, health status marked by good physical look, activity, and normal mouse behaviour. The exclusion were mice with periodontal disorder before being induced by Phorphyromonas gingivalis, marked clinically by swollen, red, tender, and easily bleeding gum. The number of the sample in this study were calculated by Federer formulation and found minimum number were 5 mice, but it was added by 2 , so that the total sample became 35 mice.

The research was started by ethical permission and clearance submission, preparation of the testing animal, as many as 35 mice which were divided into 5 random groups. Mice were induced to periodontitis by ligation using silk floss on lower left first incisor by $1 \mathrm{McF}$ arland dosage as $0.02 \mathrm{ml}$. Bacteria injection was given 1 time/ day in 3 days for 28 days. Mice periodontitis condition were checked by $\mathrm{x}$-ray shot on 5 mice, 1 mouse from each group to see the alveolar bone resorption..$^{9,10}$

ATRA consumption was given every morning for 7 days. ATRA powder of those any dosage 


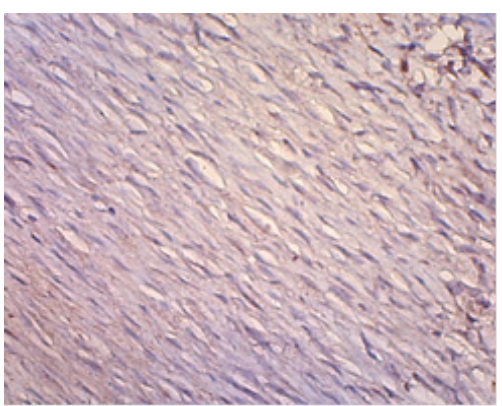

A

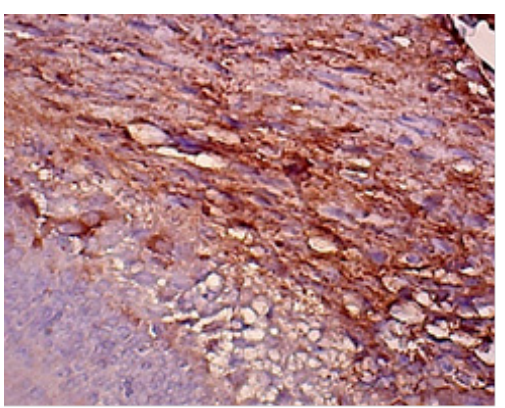

B

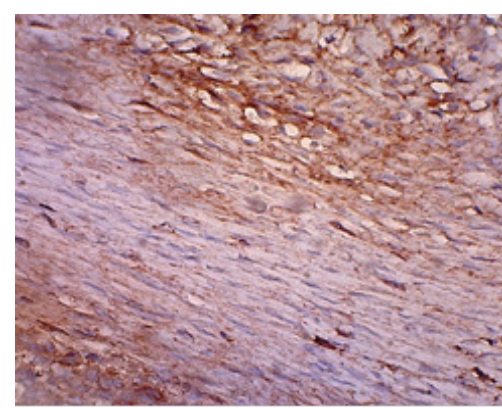

C

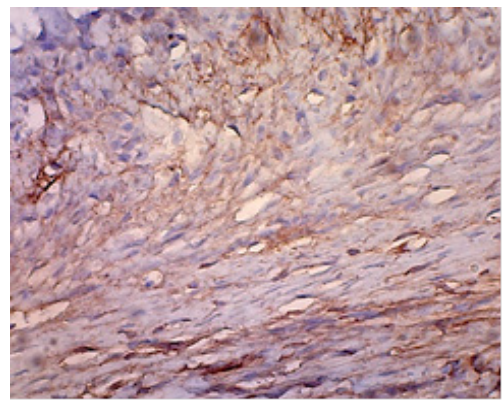

D

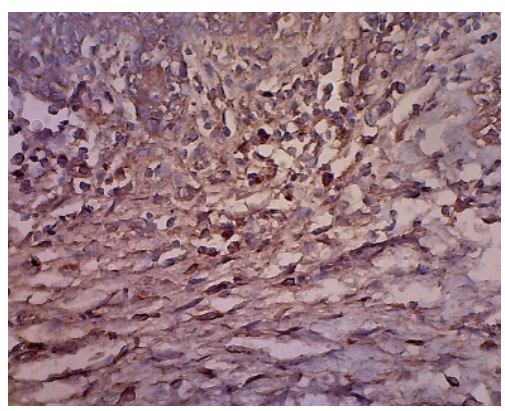

$\mathrm{E}$

Figure 1. Immunohistochemical gingiva on healthy mice Group 1 (A), sore mice Group 2 (B), ATRA at dose 5mg/kgBW Group 3 (C), ATRA at dose $10 \mathrm{mg} / \mathrm{kgBW}$ Group 4 (D), ATRA at dose $20 \mathrm{mg} / \mathrm{kgBW}$ Group 5 (E).

was dissolved in $1 \mathrm{ml}$ corn oil and was given to the testing animal orally using sonde gastrique through its palate and then pushed to esophagus. The groups which were not given ATRA Group 1 and Group 2 were given corn oil as placebo.

Preparation of animal tissues after being euthanized were retrieval of labial gingival tissues of lower left incisive. Incision was started from mesial direction to distal direction with incision width 4-6 mm from cervical direction to apical of gingival part. The processing of the tissue then was done by tissue paraffin block, deparaffinization process and continued with MMP-2 immunohistochemical staining. ${ }^{11}$

Immunohistochemistry preparat observation was done by using light microscope connected with optilab camera. MMP-2 expression shown as brown colour on tissues. MMP-2 expression calculation formula based on cell which expresses MPP-2 divided to total cell numbers in sight field multiple to 100 percent and counted each 5 sight field with 400x enlargement. ${ }^{12}$ MMP-2 expression percentage was achieved based on the formula, then they were put into MMP-2 positive area scoring and MMP-2 colour intensity score. After the preparat had been calculated and observed to the MMP-2 expression, analyze were performed.
Data analysis was done by using statistical package for social sciences software (SPSS). Data analysis was started with normality test using Saphiro-Wilk test and homogenity test using Levene test. The MMP-2 expression had not distributed normally homogen, and then KruskallWallis test were done to analyze distinction of each group, and continued with Mann-Whitney test to see the significancy of distinction group.

\section{RESULTS}

The expression of matrix metalloproteinase-2 (MMP-2) at mice was measured. Colouring result by imunohistochemical technique using MMP2 antibody had been seen as brown colour on fibroblast cells of cytoplasm and macrophage with variant intensity. The stronger colour intensity shows higher MMP-2 expression. Score assessment was done by 3 observers to achieve data validity, and using Pearson correlation test $(p<0.05)$. It was decided that observer 1 , observer 2 , observer 3 were related. Observation results of MMP-2 expression on gingiva tissue and periodotal ligament available on picture 1 below.

Based on immunohistochemistry at Figure 1 , it could be seen that macrophage cells and 
Table 1. Result of MMP-2 expression positive area score

\begin{tabular}{ccc}
\hline No. & Group & MMP-2 Positive area score average $(\%) \pm$ SD \\
\hline 1. & 1 & $0.80 \pm 0.447$ \\
2. & 2 & $4.40 \pm 0.548$ \\
3. & 3 & $3.80 \pm 0.837$ \\
4. & 4 & $3.00 \pm 1.225$ \\
5. & 5 & $1.00 \pm 0.000$ \\
\hline
\end{tabular}

Table 2. Kruskal-Wallis test result between Groups toward distinction of MMP-2 positive area percentage score

\begin{tabular}{cccc}
\hline No. & Group & Mean Rank & Sig. \\
\hline 1. & 1 & 5.00 & \\
2. & 2 & 20.80 & \\
3. & 3 & 18.10 & $0.000^{*}$ \\
4. & 4 & 15.10 & \\
5. & 5 & 6.00 & \\
\hline
\end{tabular}

Table 3. Mann-whitney test result MMP-2 positive area percentage score

\begin{tabular}{llllll}
\hline & Group 1 & Group 2 & Group 3 & Group 4 & Group 5 \\
\hline Group 1 & - & $0.006^{*}$ & $0.007^{*}$ & $0.007^{*}$ & 0.317 \\
Group 2 & $0.006^{*}$ & - & 0.212 & $0.067^{*}$ & $0.005^{*}$ \\
Group 3 & $0.007^{*}$ & 0.212 & - & 0.192 & $0.005^{*}$ \\
Group 4 & $0.007^{*}$ & $0.067^{*}$ & 0.192 & - & $0.005^{*}$ \\
Group 5 & 0.317 & $0.005^{*}$ & $0.005^{*}$ & $0.005^{*}$ & - \\
\hline
\end{tabular}

fibroblast cells of Group 1 were fewer expressing MMP-2. Group 2 was the group which expressed MMP-2 the most. Furthermore, MMP-2 positive area distribution scoring and MMP-2 colour intensity and positive area percentage on each picture were seen at Table 1.

The result above showed that Group 1 had the lowest value and Group 2 had the highest value. MMP-2 positive area percentage data in the following step was done using Kruskal-Walls to see the distinction between treated Groups. Kruskal-Walls test result can be seen on Table 2 .

Kruskal-wallis statistic test result on Table 2 showed there was MMP-2 expression difference with means $(p<0.05)$. This case showed there was distinction of MMP-2 positive area percentage which had meaning between treated groups. Furthermore, Mann-Whitney statistic test was done to observe MMP-2 positive area percentage score distinction between each group. MannWhitney test result could be seen on Table 3 .
Table 4. Result of MMP-2 colour intensity score

\begin{tabular}{ccc}
\hline No. & Group & Mean of colour intensityscore MMP-2 \pm SD \\
\hline 1. & 1 & $0.40 \pm 0.548$ \\
2. & 2 & $2.80 \pm 0.447$ \\
3. & 3 & $2.60 \pm 0.548$ \\
4. & 4 & $1.60 \pm 0.548$ \\
5. & 5 & $0.60 \pm 0.548$ \\
\hline
\end{tabular}

Table 5. Kruskal-wallis test result of MMP-2 colour intensity between Groups

\begin{tabular}{clcl}
\hline No. & \multicolumn{1}{c}{ Group } & Mean Rank & Sig. \\
\hline 1. & Healthy Mouse & 5.40 & \\
2. & Sore Mouse & 20.70 & \\
3. & ATRA $5 \mathrm{mg} / \mathrm{kgBW}$ & 19.40 & $0.001^{*}$ \\
4. & ATRA $10 \mathrm{mg} / \mathrm{kgBW}$ & 12.90 & \\
5. & ATRA $20 \mathrm{mg} / \mathrm{kgBW}$ & 6.60 & \\
\hline
\end{tabular}

Table 6. Mann-Whitney test result of MMP-2 colour intensity score based on Group

\begin{tabular}{llllll}
\hline & Group 1 & Group 2 & Group 3 & Group 4 & Group 5 \\
\hline Group 1 & - & $0.006^{*}$ & $0.007^{*}$ & $0.020^{*}$ & 0.549 \\
Group 2 & $0.006^{*}$ & - & 0.513 & $0.014^{*}$ & $0.006^{*}$ \\
Group 3 & $0.007^{*}$ & 0.513 & - & $0.031^{*}$ & $0.007^{*}$ \\
Group 4 & $0.020^{*}$ & $0.014^{*}$ & $0.031^{*}$ & - & $0.031^{*}$ \\
Group 5 & 0.549 & $0.006^{*}$ & $0.007^{*}$ & $0.031^{*}$ & - \\
\hline
\end{tabular}

Note: Source: Processed Primary Data, 2015, Information: * Different Meaning $(p<0.05)$

Mann-Whitney test result on Table 3 showed that there were different scores of MMP-2 positive area percentage with means $(p<0.05)$ on most groups, except, to Group 1 with Group 5, Group 2 with Group 3 , and Group 3 with Group 4 which had score $p>0.05$.

Based on MMP- 2 colour intensity observation on healthy mouse group, periodontitis mouse without administration of ATRA, periodontitis mouse with ATRA dosage $5 \mathrm{mg} / \mathrm{kgBW}$, periodontitis mouse with ATRA dosage $10 \mathrm{mg} / \mathrm{kgBW}$ and periodontitis mouse with ATRA dosage $20 \mathrm{mg} /$ $\mathrm{kgBW}$ can be seen on Table 4 .

Based on the observation result of MMP-2 colour intensity score on Table 4, the data was not distributed normally and but homogen. Next, transformation data and data normality test were performed again. The result showed that the data was still not normal then analyzed by Kruskallwallis statistic test to know the difference of 
MMP-2 expression colour intensity score between groups. Kruskall-wallis test result could be seen on Table 5.

This result showed that ATRA administration affecting to the degradation of MMP-2 expression. Next, a Mann-Whitney test was performed to understand the difference of colour intensity among each Group. Mann-whitney test result could be seen on Table 6 .

\section{DISCUSSION}

Research results show that the administration of all trans retinoic acid (ATRA) at dosage $20 \mathrm{mg}$ / kgBW has the most capability to inhibit MMP-2 expression, it can be seen from the percentage of MMP-2 positive area and MMP-2 colour intensity. On observation of MMP-2 positive area percentage, there were different meaning among periodontitis mouse groups, periodontitis mouse group which was given ATRA dosage $5 \mathrm{mg} / \mathrm{kgBW}$, periodontitis mouse group which was given ATRA dosage 10 $\mathrm{mg} / \mathrm{kgBW}$ and periodontitis mouse group which is given ATRA dosage $20 \mathrm{mg} / \mathrm{kgBW}$. Different signification of MMP-2 positive area among treated groups are $0.000(p<0.05)$, so it can be said that the difference among groups are meaningful. This research showeds that ATRA $20 \mathrm{mg} / \mathrm{kgBW}$ intake is giving better result toward MMP-2 area degradation compared with mouse groups given corn oil, dosage $5 \mathrm{mg} / \mathrm{kgBW}$, and dosage $10 \mathrm{mg} /$ kgBW groups.

In periodontitis mouse group which ATRA is not given, MMP-2 expression is the highest compared to other periodontitis groups which ATRA are given. This case corresponds parallelly with previous research that said MMP proteolytic enzymes is a indicator of inflammatory condition that its amount is proportional to the severity of the inflammatory condition. ${ }^{13}$ MMP enzyme is excreted by any kind of connective tissue and proinflamation cell include fibroblast, osteoblast, endothelial, and macrophage so the MMP enzyme activity is often found in inflammatory condition. ${ }^{14}$ Periodontitis recuperation formed on regeneration and structure refinement are known to occur through treatment procedure or natural ways. ${ }^{15}$

Degradation of MMP-2 expression on periodontitis group where ATRAis given corresponds with previous research that enchancement of MMP gen expression could be down regulated by ATRA which has been entered into cells. ATRA enters cell from cytoplasm to nucleus, afterward, ATRA will be bound with its receptor and regulates transcription from any gen which finally can reduce MMP-2 activity. ${ }^{16}$ The decline of MMP-2 expression on periodontitis group can happen because of endurance and age factors showing body's metabolism that is still good. ${ }^{17}$ Immune cells will give response toward inflammation so there will be natural recuperation process. ${ }^{18}$

On observation of MMP-2 colour intensity, there is meaningful difference among whole groups, except in the healthy mouse group when compared with ATRA $20 \mathrm{mg} / \mathrm{kgBW}$ dosage mouse group and sore mouse group which compared with ATRA $5 \mathrm{mg} / \mathrm{kgBW}$ dosage mouse group. The case is caused by colour intensity that looks almost similar between them. MMP-2 expression with weak intensity looked on healthy mouse group and ATRA $20 \mathrm{mg} / \mathrm{kgBW}$ dosage mouse group. MMP. 2 expression with medium intensity is on ATRA 10 $\mathrm{mg} / \mathrm{kgBW}$ dosage mouse group. Meanwhile, MMP-2 expression with strong intensity is found on sore mouse group and ATRA $5 \mathrm{mg} / \mathrm{kgBW}$ dosage mouse group, It proves that ATRA intake with high dosage affects in declining the MMP-2 colour intensity.

Previous research showed that ATRA intake with higher dosage had better effectivity in reducing inflammatory on periodontitis case if compared with lower dosage. ${ }^{19}$ The case is also corresponding with previous research that said that ATRA $15 \mathrm{mg} / \mathrm{kgBW}$ plays a role in soft tissues inflammatory on the back foot of lab mouse which is better than lower dose. The research showed anti-inflammatory effect, $20 \mathrm{mg} / \mathrm{kgBW}$ dosage was better than $5 \mathrm{mg} / \mathrm{kgBW}$ dosage and $10 \mathrm{mg} / \mathrm{kgBW}$ dosage.

Intake $5 \mathrm{mg} / \mathrm{kgBW}$ of ATRA positive area percentage, there is no meaningful difference after being tested statistically. This is because there is just a few degression on MMP-2 positive area of ATRA $10 \mathrm{mg} / \mathrm{kgBW}$ and ATRA $5 \mathrm{mg} / \mathrm{kgBW}$ dosage intake. The difference which is significant can be seen from MMP- 2 colour intensity difference for both groups. This proves that ATRA $10 \mathrm{mg} /$ kgBW dosage intake can reduce MMP-2 colour intensity than $5 \mathrm{mg} / \mathrm{kgBW}$ which cannot reduce the percentage of MMP-2 positive area maximally and significantly. 
For ATRA $5 \mathrm{mg} / \mathrm{kgBW}$ dosage, the degression of MMP-2 expression amount is lighter than the sore mouse group. This case corresponds with previous research which showed that ATRA $5 \mathrm{mg} /$ $\mathrm{kgBw}$ can reduce inflammatory but not optimally if compared with higher dosage. ${ }^{20}$ This study shows that MMP-2 expression depends on dosage which is given (dose-dependent). According to previous research, higher dosage of ATRA but still on the safe limit shows inflammatory recuperation in the form of better collagen fibers density. ${ }^{11}$

The dosage which is safe to be used for animal testing is about $5-20 \mathrm{kgBW}^{20}$ and dosage above $20 \mathrm{mg} / \mathrm{kgBW}$ can raise hepatotoxicity in mouse if consumed everyday until 30 days. Administration of $50 \mathrm{mg} / \mathrm{kgBW}$ dosage can cause death for the mouse if consumed everyday until 60 days. The study showed that the higher administration dosage of ATRA caused the lower the MMP-2 proteolytic enzyme expression. Safety dosage amount of ATRA still need to be investigated further.

On periodontitis mouse group, the enhancement of highest percentage of positive area and MMP-2 colour intensity occured if compared with other groups. This is because the group is only given corn oil as placebo. Corn oil has no recuperation effect of inflammated tissues. ${ }^{21}$ The histologic description of periodontitis group without ATRA consumption shows broken tissues, full of inflammatory cells and higher percentage of MMP-2 positive area on connective tissues and stronger colour intensity of MMP-2 than treated Groups.

\section{CONCLUSION}

ATRA dose of $20 \mathrm{mg} / \mathrm{kgBW}$ is the most effective dose in inhibiting the expression of MMP-2 in mice models of periodontitis when compared with other doses.

\section{REFERENCES}

1. Tampubolon. Dampak karies gigi dan penyakit periodontal terhadap kualitas hidup. Medan: Universitas Sumatera Utara Press; 2010.

2. Stingu CS. Microbial profile of patients with periodontitis compared with healthy subject.
Quintessence Int J 2012;43:23-31.

3. Newman MG, Takei HH, Carranza FA. Carranza's clinical periodontology. $11^{\text {th }}$ ed. Philadelphia: WB. Saunders; 2012.

4. Guimaraes DA, Rizzi E, Ceron C, Oliveira A. Doxycycline dose-dependently inhibits MMP2-mediated vascular changes in hypertension. Basic Clin Pharm J 2005;108(5):318-25.

5. World Food Programme. Peta ketahanan pangan dan kerentanan pangan Indonesia. Jakarta: Dewan Ketahanan Pangan Departemen Pertanian Republik Indonesia; 2009.

6. Zhu YK, Liu X, Ertl RF, Kohyama T, Wen FQ, Wang $H$. Retinoic acid attenuates cytokinedriven fibroblast degradation of extra-cellular matrix in threedimensional culture. Am J Res Cell Mol Biol 2001;25(5):620-27.

7. Riessen R. All-trans retinoic acid regulates proliferation, migration, differentiation, and extracellular matrix turnover of human arterial smooth muscle cells. Cardiovascular Res 2001;4(1):851-62.

8. Sandoval R, Alique M, Molina C, Lucio F. The oral administration of retinoic acid enhances nociceptive withdrawal reflexes in rats with soft-tissue inflammation. Inflam Res 2004;53(7):297-303.

9. Praptiwi H. Inokulasi bakteri dan pemasangan cincin atau ligatur untuk induksi periodontitis Tikus. Maj Ked Gig 2008;15(1):81-4.

10. Nugraha LS. Cara dan rute pemberian obat pada hewan percobaan mencit. Semarang: Farmasi Theresiana. 2011.

11. Hanafi P, Sulistyowati K. Pengaruh suplementasi all-trans asam retinoat (ATRA) pada periodontitis. Link Journal 2012;8(3):361-67.

12. Herawati Y. Pemberian oral ekstrak daun pegagan (Centella asiatica) lebih banyak meningkatkan jumlah kolagen dan menurunkan ekspresi MMP-1 Pada Tikus Wistar (Rattus norvegicus). Tesis. Denpasar: Program Studi Ilmu Biomedik Program Pascasarjana Universitas Udayana; 2014.

13. Amalinei C. Matrix metalloproteinases involvement in pathologic conditions. Romanian J Morphol Embryol 2010;51(2):21528.

14. Verma RP, Hansch C. Matrix metalloproteinases: Chemical-biologic function. Bioorganic Medic Chem J 2000;15(6):2223-68. 
15. Polimeni G, Xiropaidis AV, Wukesjo UM. Biology and principles of periodontal wound healing. Periodontol 2006;41(1):30-47.

16. Dutta A, Sen T, Chatterjee A. Studies on multifunctional effect of all-trans retinoic acid (ATRA) on matrix metalloproteinase-2 (MMP-2) and its regulatory molecules. Oncol J 2010;4(3):409-18.

17. Dumitrescu AL. Etiology and pathogenesis of periodontal disease. New York: Springer; 2010.

18. Mariano FS, Sardi JC, Duque C, Hofling JF. The role of immune system, in the development of periodontal disease. Revista Odonto Cienca
2010;25(3):300-5.

19. Praptiwi Muis, Hadisaputro S. Sumbangan alltrans asam retinoat (ATRA) bagi penyembuhan periodontitis. Media Medika Indonesiana 2011;45(3):169-73.

20. Ferguson AS, Siitonen PH, Cisneros J, Gough B. Steady state pharmacokinetics of oral treatment with all-trans retinoic acid in male adults rats. Pharmacol Toxicol J 2005;98(1):582-7.

21. Feng $Z$, Winberg A. Role of bacteria in health and disease of periodontal tissue. Periodontol 2006;40(1):50-76. 